\title{
Strategie konstruování jazykového obrazu ukrajinské krize na př́kladu vybraných sociálních médií a deníku Komsomolskaja pravda
}

\section{The Strategy of Constructing a Language Image of the Ukrainian Crisis at the Example of Selected Social Media and the Newspaper Komsomolskaya Pravda}

Eva Niklesová - Ekaterina Shlygina (Praha, Česká republika)

\begin{abstract}
:
The present article discusses the role of social media in organizing large-scale social protest movements at the example of organizing Euromaidan where social media represented the key platform for coordinating protest activities. Furthermore, the article deals with the function of the media in the context of the so-called hybrid war in which the media became the key offensive "soft" instrument which has largely hit the course of events. The last part of the article analyzes the daily Komsomolskaya Pravda to find out how it informed about the Ukrainian crisis. The special attention focuses on the analysis of the strategies that are connected with the framework concept mainly related to the choice of expressive lexical units, stereotype phrases, the narrative presentation of events etc.
\end{abstract}

Key words:

Euromaidan; social media; new propaganda; media manipulation; framing; Komsomolskaya pravda 


\section{Euromajdan ${ }^{1}$ a sociální média}

Události spojené s ukrajinskou krizí vstoupily do oblasti mediálních, kulturálních, sociálních, politických a dalších studií - mj. - i v souvislosti s úlohou a rolí sociálních médií při organizování rozsáhlých společenských protestních hnutí. Sociální média sehrála při svolání a celkovém průběhu Euromajdanu ${ }^{2}$ nezastupitelnou roli. Výzva k občanským protestům byla na sociálních sítích uveřejněna již v noci 21 . listopadu 2013 a na kyjevském náměstí Nezávislosti se sešlo několik tisíc demonstrantů, ${ }^{3}$ kteří na výzvu reagovali. Na Twitteru byl založen oficiální profil \#euromaidan. ${ }^{4}$ Sociální sítě se tak staly klíčovými platformami pro koordinaci protestních aktivit a sdílení informací, fotografií a videí o protestních číslech, místech a otázkách, jako je policejní násilí, provokace apod. ${ }^{5}$

Významnost a nezastupitelnost sociálních médií při průběhu a organizování Euromajdanu a z hlediska jeho dlouhodobého politického a historického dopadu se role sociálních médií stala předmětem četných výzkumů v oblasti sociálně-mediální perspektivy. Euromajdanské protestní hnutí začalo být chápáno např. jako „opravdu

1 Slovem Euromajdan (orig. Euromaidan) jsou označovány masové občanské protesty, které byly započaty 21. listopadu, po odmítnutí podpisu Asociační dohody s EU tehdejším ukrajinským prezidentem V. Janukovyčem [SHVEDA, HO PARK 2015, 85n]. Tamtéž podrobněji srov. k podstatě a historickým důsledkům revoluce Euromajdan.

2 Probíhala rovněž série provládních demonstrací, tzv. Antimajdan, jichž se účastnili př́innivci prezidenta Janukovyče. 25. listopadu 2013 se provládní demonstrace uskutečnila v Kyjevu, podle různých zdrojů se jí zúčastnilo od 3 do 10 tisíc protestujících [Maidan... 2013].

3 Neexistují přesné údaje o tom, kolik osob se účastnilo protestních akcí v Kyjevu a v ostatních městech Ukrajiny. Světová média zveřejňovala data o jednotlivých dnech protestů, např́klad podle deníku Guardian vyšlo 24. listopadu 2013 do ulic Kyjeva více než 100 ooo protestujících, nejvíce od tzv. Oranžové revoluce z roku 2004. V ten den policie na rozehnání protestujících začala používat slzný plyn [GRYTSENKO 2013]. Nespokojenost lidí na Euromajdanu a možná i následnou eskalaci konfliktu způsobila samotná vláda prezidenta Viktora Janukovyče tím, že 30. listopadu 2013 poslala na odpor demonstrantům speciální policejní jednotku Berkut [WOOD, POMERANZ, MERRY, TRUDOLYUBOV 2016, xi-xiv].

4 Hashtagy (Ukrainian \#євромайдан, ruský \#евромайдан a anglický \#euromaidan) se objevily první večer protestů a ihned se staly velice užitečným nástrojem pro předběžnou koordinaci a pro informování online uživatelů, a to jak na Ukrajině, tak i v dalších zemích. Během počáteční fáze protestů (25. listopadu 2013) bylo zveřejněno asi 3200 tweetů za hodinu a až 4800 tweetů za hodinu bylo uveřejněno 30. listopadu 2013, ve dni prvního násilného policejního zásahu proti demonstrantům [LOKOT 2013].

5 Podle Ronzhyna byla úloha sociálních médií klíčová zejména v rovinách vysoké úrovně protestní samoregulace a rozsáhlého amatérského zpravodajství. Dále Ronzhyn uvádí, že „ukrajinské protesty se staly nejen jednou z nejsilnějšich evropských protestních hnutí v nedávné minulosti, ale také nejvíce společenskými. Hashtag \#euromaidan a jeho ukrajinské a ruské verze zůstaly na dlouhou dobu hlavním tématem ukrajinského internetového segmentu a také byly široce používány a diskutovány $v$ rusky mluvicím internetu, zatímco aktualizace Facebooku byly běžně citovány ukrajinskými a západními médii." [RONZHYN 2014]. 
první úspěšné povstání sociálních médii“ ("first truly successful social media uprising“) [TUCKER, METZGER, PENFOLD-BROWN, BONNEAU, JOST, NAGLER 2014], ${ }^{6}$ přičemž autoři této teze využili daných okolností $\mathrm{k}$ vyvozování obecnějších závěrů o sociálních dopadech mediální politické participace, a to na pozadí politologie a sociální psychologie. Na základě jejich analýzy sociálních mediálních dat mj. vyplynulo, že většina protestních hnutí bude v budoucnu představovat významnou úlohu pro sociální média, že různé platformy sociálních médií budou s největší pravděpodobností hrát naprosto odlišné role, že dny protestů v nepř́tomnosti výrazné př́tomnosti sociálních médií se blíží ke svému konci apod. [RONZHYN 2014]. Současně je však třeba brát při vyvozování těchto obecných závěrů - zejména $\mathrm{z}$ pohledu sociálně-mediální perspektivy - v potaz lokální specifika mediální krajiny, v tomto př́padě ukrajinské, nebot např. podle průzkumu provedeného v březnu $2016 \mathrm{v}$ Kyjevě Goršeninovým institutem (Gorshenin Institute) hraje hlavní roli při informování veřejnosti na Ukrajině televize; podle výsledků tohoto výzkumu $88 \%$ Ukrajinců použivá převážně televizi, aby zůstávali informováni o aktuálních záležitostech [PÖRZGEN 2016, 3]. Dále je třeba si uvědomit, že hlavní ukrajinské mediální společnosti, a zejména vlivné soukromé televizní kanály, jsou stále ovládány oligarchy [PÖRZGEN 2016, 13], že revoluční události 2013-2014 sloužily jako katalyzátor pro vznik alternativních veřejných komunikačních kanálů, že přes výše uvedené označení „first truly successful social media uprising " mělo v době revolučních událostí 2013-2014 pouze $37,49 \%$ ukrajinské populace možnost nepřerušeného př́stupu $\mathrm{k}$ internetu a že velká část ukrajinského obyvatelstva nemá $\mathrm{k}$ internetu denní př́istup [ONUCH 2015].

\section{Ukrajinská krize, hybridní válka a nová propaganda}

Události spojené s rusko-ukrajinským konfliktem vnesly do evropského diskurzu rovněž okruh otázek, problémů, polemik a diskuzí, jež se dotýkají - dnes již možná dokonce módních a nadužívaných - pojmů informační/hybridní/propagandistická/ /alternativní/nelineární válka, ${ }^{7}$ dezinformace, psychologické operace, psychologický

6 Dřívější protestní hnutí označovaná jako revoluce na sociálních médiích byla následně kritizována za to, že neměla na sociálních médiích př́liš důležitou aktivitu (Moldavsko, Arabské jaro), nebo proto, že měla velkou př́tomnost v sociálních médiích, ale nakonec dlouhodobě nepůsobila jako protestní hnutí (španělské Los Indignados, Occupy Wall Street, Gezi Park v Turecku) [RONZHYN 2014].

7 Balabán, Pernica a kol. [BALABÁN, PERNICA 2015, 38] hovoří o tzv. hybridním zpưsobu válčení (hybrid warfare), o nové metodě boje, „která byla uplatněna Ruskem při $v$ konfliktu s Ukrajinou na Krymu, východní a jihovýchodní Ukrajině“ a která je „postavena na asymetrické a na první pohled nečitelné taktice boje." Tito autoři dále uvádějí, že autorství termínu hybridní válka je připisováno Frankovi G. Hoffmanovi, který „nepoužil primárně pojem hybridní válka, ale hybridní hrozby" [BALABÁN, PERNICA 2015, 38]. Ke zrodu pojmů hybridní válka a hybridní hrozba srov. např. [KUBEŠA, SPIŠÁK 2011]. Podle Zelenky [ZELENKA 2014] nemá „termín hybridní válka žádnou 
tlak atp., široké škály nevojenských nástrojů, které jsou užívány k vyvíjení tlaku a k ovlivňování chování zemí. ${ }^{8}$

V kontextu hybridní války se média stala klíčovým útočným „měkkým“ (spolu)nástrojem, významně zasahujícím do průběhu a výsledku událostí - napr. Rácz z Finského institutu mezinárodních vztahů hovoří o tom, že jednou z podmínek pro možnost vedení hybridní války je „silné zastoupení médií útočící země v zemi cílové “, že dobře fungující média umožňují útočníkům generovat a posilovat nedůvěru vůči centrální vládě, izolovat napadenou oblast od veškerých informací pocházejících z hlavního města a dezinformovat cílovou zemi i mezinárodní komunitu [RÁCZ 2015]. Opět tak výrazně a zásadně vyvstal mediálně-manipulativní aspekt nepřiznaného „zpracování vědomí lidí prostřednictvím médii za účelem systematického a cílevědomého ř́zení a formování jejich vědomí, myšlenek a pocitư “ [REIFOVÁ 2004, 127] a akcentace nutnosti kritického myšlení, rozvíjení mediální gramotnosti a celkového kladení důrazu na ověřování a komparaci údajů z různých informačních pramenů. Díky rozmachu internetu a možnosti čerpat (pseudo)informace z nespočtu zdrojů nelze hovořit o klasické propagandě, jakožto formě jednostranného persvazivního/manipulativního působení, o „pouhém“ ovlivňování, přesvědčování apod., nýbrž spíše o „nové propagandě“ [KŘÍŽ, SHEVCHUK, ŠTEVKOV 2015, 10]. V případě prostředků užívaných během hybridní války tak sice možná nejde o tolik explicitní/vnějškově viditelné formy klamu a ofenzivy, avšak moderní recipient se dostává do situace neustálé oscilace mezi totální/patologickou nedůvěrou v informace zprostředkované médii a mezi recepčně přivětivějším pokušením ztotožnit se s obsahy, které si sami svobodně vyhodnotili jako „ty správné, na které se lze spolehnout“, resp. na ty, které jsou jim názorově nejbližší.

\section{Zpravodajství o ukrajinské krizi na příkladu deníku Komsomolskaja pravda}

Skutečnost, že recipienti - nejen v kontextu hybridní války, ukrajinské krize apod. mohou akceptovat neověřené informace, dezinformace a účelově jednostrannou prezentaci událostí a považovat je za „pravdivé“ či verifikované, může významně souviset $\mathrm{s}$ vědomou prací se stereotypy, s předsudky, žádnými či marginálními bezprostředními zkušenostmi $\mathrm{s}$,jinou“ kulturou, ${ }^{9}$ avšak rovněž i s případnými

jasnou definici, většina teoretiků zabývajících se tímto údajným fenoménem se shoduje v tomto: co z hybridní války dělá válku hybridní, je souběžné použití nekonvenčních technik společně s klasickými konvenčními prostředky vedení války. Tyto prostředky pak ještě může doplňovat široká škála dalších opatření namírených na protivníkovo zápolí - zpravidla psychologické operace a kybernetické útoky."

$8 \quad$ K tomuto dále srov. napr. [VEEBEL 2015].

9 Srov. např. vyjádření českého žurnalisty J. Pazderky, bývalého zahraničního zpravodaje v Rusku, v rozhovoru J. Gazdíka Slova, která zabíjí. Ruská státní média jsou vojenská zbrañ, v němž hovoří 
nedostatečnými znalostmi o fungování mediálního trhu určité země. ${ }^{10}$ Média tak mohou (spolu)vytvářet účelově modelovanou mediální reprezentaci událostí a účinně manipulovat s lidskými emocemi, přičemž „sami Rusové mají pro [...] propagandou zpracované lidi príléhavý název: zombirovannyje ljudi (uhranutí lidé)“ [GAZDÍK 2015]. S cílem zjistit, jakým způsobem probíhá v ruských médiích informování o ukrajinské krizi a jakými způsoby může být dosaženo co nejvyšší recepční přitažlivosti tohoto typu zpráv, byl pro ilustraci zvolen deník Комсомольская правда ${ }^{11}$ z období od ledna do března 2014. K volbě tohoto deníku bylo přistoupeno $\mathrm{z}$ toho důvodu, že v Rusku patří $\mathrm{k}$ deníkům nejčtenějším. ${ }^{12}$ Pro zpracovaní byly vybrány články, v nichž byla

např. o minimální zkušenosti běžných Rusů s Evropou, „o které mají velmi povrchní znalosti. Ve vědomí lidí tak dodnes vládne spousta sovětských stereotypů o imperialismu, banderovcích a já nevím o čem všem ještě. Stačí se těchto témat jen dotknout a jakákoliv další diskuse je nemožná. Tento mix vytvář́ velmi ničivou zbraň, kdy jsou lidé ochotni věrit i těm nejabsurdnějším zprávám o křižování dětí zaživa, jejich opékání v troubě, lidojedství..." Pazderka se v tomto rozhovoru zmínil rovněž o tom, že „z médií a novinářù se stávají regulérní zbraně, takže přestávají plnit základní informační funkci.“ Samotný předpoklad o čistě informační funkci médií však bývá problematizován, zpochybňován, či zcela zavržen [GAZDÍK 2015].

10 Ruská mediální realita se výrazně proměnila s nástupem vlády současného prezidenta Vladimira Putina. Dvořák [DVOŘÁK 2010] uvádí, že „rozhodující pro dnešní podobu ruského mediálního světa je rok 20oo, kdy se hlavou státu stává Vladimír Putin. Především velké televize [...] se znovu dostávají pod prímou či nepřmmou kontrolu státu. Totéž platí i pro největši média tištěná, jako jsou deníky Izvěstija či Kommersant anebo týdeník Itogi, tedy pro sdělovací prostředky, které pred Putinovým nástupem společněs největšimi televizemi $v$ Rusku utvářely relativně liberální politické počasí. Vytváráejí ho i dnes, jen s tím rozdílem, že liberální už se mu rozhodně ř́kat nedá. [...] Skutečně nezávislí novinář́ jsou $v$ Rusku naštěstí také, ale ti mají $k$ dispozici bud’ internet, anebo vybraná média typu moskevského listu Novaja gazeta či rozhlasovou stanici Echo Moskvy, tedy média s omezeným dosahem, která Kreml trpí proto, aby se vytvárelo zdání demokracie a plurality názorů." Od počátku vládnutí Vladimíra Putina se v ruských médiích začaly objevovat podobné motivy jako za dob Sovětského svazu. Do televizí se začaly vracet výrazy jako „veliké Rusko“, „návrat ruských zemí“ nebo „zvedáme se z kolen“. Do podstaty ruské mediální krajiny výrazně zasáhlo známé Putinovo opatření z roku 2016, kdy došlo $\mathrm{k}$ omezení podílu zahraničních společností v ruských médiích, která se do té doby „týkala televizí a rozhlasových stanic, od roku 2016 budou platit pro všechna elektronická $i$ tištěná média s výjimkou těch, která fungují na základě mezinárodních dohod, jako je napríklad televize Euronews" [DORAZÍN 2014]. Podle informací v článku Russia tightens limit on foreign ownership of media ruská legislativa zakazuje organizacím a zahraničním občanům či firmám zakládání nebo držení více než $20 \%$ podílu v ruských mediálních obchodech [LUHN 2014]. K přehledu ruských médií srov. např̀. seznam Ministerstva zahraničních věcí [Ruská... 2017].

11 Deník Komsomolskaja pravda byl založen v roce 1925 a patří v Rusku mezi nejčtenější. Původně tento deník sloužil jako oficiální tiskový orgán Ústředního výboru Komsomolu, od roku 1990 však již tuto funkci neplní a přetavil se po podoby ruského bulvárního deníku s celostátním dosahem. Podle BBC monitoringu ruských médií [The Press... 2008] Komsomolskaja pravda dosáhla svého nejvyššího objemu v roce 1990, kdy se prodalo téměř 22 milionů exemplářů.

12 Podle informace Ministerstva zahraničních věcí České republiky Ruská média se jedná o nejčtenější deník „všeobecného zaměření s lehce bulvárním nádechem “ [Ruská... 2017]. Na základě zjištění TNS Gallup Media z roku 2008 byla Komsomolskaja pravda nejnavštěvovanější ruskou zpravodajskou webovou stránkou [FEILITZEN, PETROV 2011, 26]. Komsomolskaja pravda se - podle údajů ruské 
zmiňována slova či kolokace Krym, Krymská krize, Ukrajinská krize nebo Majdan (Крым, Крымский кризис, Украинский кризис nebo Майдан). ${ }^{13}$

Pokud bychom měli shrnout způsoby informování o ukrajinské krizi, můžeme zde identifikovat několik vzájemně se prolínajících zpravodajských strategií, které by bylo možno souhrnně interpretovat na pozadí konceptu rámcování (framing) ${ }^{14}$, kdy jde zejména o výběr určitých aspektů medializované reality a zvyšování jejich významnosti pečlivě volenými frázemi, stereotypními výroky, frázemi apod. S tímto se $\mathrm{v}$ analyzovaném deníku setkáváme často, př́iznačná je volba emočně a expresivně zabarvených lexikálních jednotek. Pro ilustraci uvedme článek na čtvrté straně vydání z 23. ledna 2014, ${ }^{15}$ který přináší osobní pohled na situaci v Ukrajině ruského populárního zpěváka Jurije Lozy. Jurij Loza hovoří o tom, že „tolik kyjevských obyvatel přišlo na náměstí zničit svou vlastní zemi“ („,столько киевлян пришли на площадь разваливать собственную страну“), о tzv. „пегоzитпи́ch sousedech“ („неразумные соседи“), о „stovkách tisících hladovějicích Ukrajincü“ („сотни тыссяч голодных украинцев“) apod. Implementaci osobního pohledu populární osobnosti na události spojené s ukrajinskou krizí můžeme označit jako poměrně účinnou žurnalistickou strategii, jejíž cíl spočívá ve snaze ztotožnit se $s$ tímto názorem a účinně prohloubit proklamovaný úhel pohledu. $V$ této souvislosti je možno uvést další př́klad této techniky - rozhovor se zpěvákem a poslancem Iosifem Kobzonem v článku z 27. 2. 2014. ${ }^{16}$ Rozhovor je věnován Ukrajině a vyskytují se zde např. tyto výroky: „Не приведи господь, если Россия отвернется от Украины. Это будет самая большая беда, хуже, чем Майдан“, „Не допустите братья-украинщы войны с Россией! Эта ваша гибель в этой войне“. Recepс̌ní údernost je zde opět umocněna emočně zabarveným lexikem, vyvoláváním pocitu bezmoci a beznaděje a odkazem na př́ibuznost národů. Za další prostř̌edek rámování v deníku Komsomolskaja pravda můžeme označit - dnes již klasický - prostředek narativního podání události ve formě

agentury Медиалогия, která se zabývá automatizovaným monitoringem masových a sociálních médií v reálném čase - každý měsíc objevuje v žebříčku pěti nejcitovanějších novin v sociálních a masových mediích v Rusku nebo v jednotlivých regionech. Srov. např. údaje za ř́jen 2016, kdy Komsomolskaja pravda byla s 668716 odkazy nejvíce citované masové médium na sociálních médiích [SMI... 2016]. Rovněž podle ruské agentury Ex Libris, která se zaměřuje na monitoring a analýzu ruských masových a sociálních, je zřejmé, že deník Komsomolskaja pravda zůstává mezi nejpopulárnějšími v Rusku. Tato analýza vychází z odborné metodiky ratingu tištěných publikací, která hodnotí jejich popularitu ze tř́ stran: od čtenářŭ, novinářů a inzerentů. Výzkumná agentura Ex Libris je řádným členem Mezinárodní asociace pro měření a vyhodnocování mediální komunikace. Podrobněji srov. [Agentstvo... 2010].

13 Uvedená čísla jsou $\mathrm{k}$ dispozici online [Archiv... 2018].

$14 \mathrm{~K}$ teorii framingu srov. napr. [McCOMBS 2009].

15 Článek je dostupný online [LOZA 2014].

16 Článek je dostupný online [GAMOV, KOBZON 2014]. 
svědectví či výpovědi „obyčejného člověka“. ${ }^{17}$ Tento prostředek, který opět pracuje s emočním nábojem a který má posílit obsahovou autenticitu, byl užit např́ílad ve vydání analyzovaného deníku z 3. března 2014 (s. 5). ${ }^{18}$ Jedná se o článek «Уpa! Это наша «русская весна», který obsahuje reakce obyvatel krymského poloostrova na zprávu o schválení použití ruských vojenských sil.: „, уж и не думал что дождусь“, „Мы такими счастливыми себя не чувствовали, даже когда наконеи удалось квартиту купить!" ad., a to v duchu všeobjímající radosti a oslav. Můžeme zde opět diskutovat o zpravodajské objektivitě a o př́padném podporování tzv. tunelového vidění zveřejněním pouze jednoho úhlu pohledu. Komsomolskaja pravda se rovněž věnovala referendu o sloučení Krymu s Ruskem, ${ }^{19}$ a to např́iklad v článku „За воссоединение с Россией - 96,77\% крымчан“ z 18. 3. 2017 (s. 3). V článku se vyskytuje věta „За то чтобы остаться в составе Украины, отдали голоса лишь 2,51\% крымчан“, přičemž slovo „лишь“ může bagatelizovat významnost tohoto počtu. Rovněž tvrzení „Явка составила 83,1 \%. Это рекордный показатель активности крымчан за всю постсоветскую историю“ žongluje s výrazem „рекордный показатель“, nebot není zřejmé, k jakému jinému hlasování se tato informace o rekordní účasti vztahuje. $\mathrm{V}$ tomto př́ípadě jde o užití jazykového prostředku, který pracuje s aspektem přesnosti vyjádření ve snaze podpořit zdání o informační relevanci. ${ }^{20}$ Druhý článek na téže stránce ${ }^{21} \mathrm{~s}$ názvem Tbl $\mathrm{Hau}$, a Mbl mвои je věnován demonstracím na podporu sloučení Krymu s Ruskem, probíhajícími v celé zemi. $Z$ věty „И вот полуостров на черном море снова станет российской землей по воле своих жителей "se čtenář dozvídá, že Krym již byl součástí Ruska a že k rozhodnutí dobrovolného „návratu“ bez nátlaku došlo samotnými obyvateli Krymu („Решение жителей Крыма и Севастополя - историческое событие, на референдуме братский народ высказал свое мнение и это для нас главный аргумент. Это действительно всенародный праздник“ - věta, která se snaží přesvědčit čtenáře, že sloučení Krymu s Ruskem je „историческое событие“ a že krymský národ je „братский“), přičemž toto tvrzení lze nalézt i v dalších článcích na toto téma. Fixace povědomí o tom, že Krym by se měl navrátit Rusku, je umocněna zveřejněním dvou sociologických průzkumů, které proběhly v Rusku a podle nichž je „большинство россиян за возвращение Крыма“. Opět se zde operuje s pojmem „návrat“, jehož konotace mají nabudit dojem oprávněnosti anexe Krymu.

17 Reifová hovoří o lidsky jímavých příbězích, tzv. „human interest“ či „human touch stories “ [REIFOVÁ 2004, 168].

18 Článek je dostupný online [OVČINNIKOV 2014].

19 Článek je dostupný online [RJABCEV, ROGOZA 2014].

20 K nepřesnostem plynoucím $\mathrm{z}$ adherentní a inherentní jazykové nepřesnosti ve zpravodajských obsazích srov. [JíLEK 2015, 41-44].

21 Článek je dostupný online [Ty... 2014]. 


\section{Závěr}

Události spojené s rusko-ukrajinským konfliktem a způsob jejich zobrazování v médiích vnesly do evropského diskurzu mnoho otázek, které se - mj. - dotýkají role sociálních médií v průběhu těchto konfliktů. Odborné úvahy o roli sociálních médií při organizování Euromajdanu získaly širší dosah a zabývají se hledáním odpovědi na otázky ohledně budoucích strategií při využití sociálních médií v rámci organizování hromadných akcí. Tyto úvahy poukazují na to, že protesty bez využití sociálních médií jsou již těžko myslitelné, lišit se však zřejmě bude sofistikovanost jejich využití a míra uživatelů $\mathrm{v}$ závislosti na mediální krajině a možnosti (svobodného) př́istupu k médiím. Na druhé straně však budou mít své nezastupitelné místo i média tradiční, která zpravidla usilují o tvoření a neustálé potvrzování uměle vytvářené mediální (pseudo)reality za pomoci prostředků souvisejících s recepční atraktivitou (jednoduchý jazyk, úderná hesla, emoční náboj, osobní svědectví, rozhovory se slavnými osobnostmi ad.). Tradiční média k tomuto účelu - jak bylo ilustrováno na deníku Komsomolskaja pravda - používají spektrum zpravodajských strategií, jež se dotýkají konceptu tzv. rámcování.

\section{Literatura:}

Agenstvo Ex Libris predstavljajet Title Popularity Ranking (TPR) - rejting populjarnosti rossijskich SMI. (2010). Ex Libris, 25. 2. 2010. <http://exlibris.ru/news/agentstvo-exlibris-predstavlyaet-title-popularity-ranking-tpr-rejting-populyarnosti-rossijskihsmi/>. [online]. [cit. 20. 4. 2016].

Archiv izdanija Komsomol'skaja pravda. Moskva. (2018). <http://pressa.ru/ru/ magazines/komsomolskaya-pravda-moskva/archive?date_start $=2014^{-1-23 \& d a t e}$ _ end $=2014-3-17 \# />$. [online]. [cit. 30. 8. 2018].

BALABÁN, M., PERNICA, B. (2015): Bezpečnostní systém ČR: problémy a výzvy. Praha. DORAZÍN, M. (2014): Rusko zpř́snilo podmínky pro zahraniční vlastníky médií $v$ zemi. iRozhlas. <https://www.irozhlas.cz/zpravy-svet/rusko-zprisnilo-podminkypro-zahranicni-vlastniky-medii-v-zemi_201410151134_vkourimsky>. [online]. [cit. 25. 9. 2016].

DVOŘÁK, L. (2010): Ruská média od Lenina k Putinovi. Týdeník Rozhlas 20, 2010, č. 15. $<$ http://www.radioservis-as.cz/archiv10/15_10/15_tema.htm>. [online]. [cit. 12. 9. 2016].

FEILITZEN, C. von, PETROV, P. (eds) (2011): Use and Views of Media in Sweden \& Russia. A Comparative Study in St. Petersburg \& Stockholm. Stockholm. 
GAZDÍK, J. Slova, která zabijí. Ruská státní média jsou vojenská zbraň. Rozhovor o propagandě s novinářem Josefem Pazderkou. Aktálně.cz, 19. 8. 2015. <https://zpravy. aktualne.cz/zahranici/rozhovor-ruska-statni-media-regulerni-vojenskazbran/r $5311 \mathrm{e} 67 \mathrm{c} 427811 \mathrm{e} 5 \mathrm{a} 705002590604 \mathrm{f} 2 \mathrm{e} /$ ?redirected $=1504518687>$. [online]. [cit. 19. 8. 2016].

GAMOV, A, KOBZON, I. (2014): Mne za Ukrainu-nen'ku bol'no... Fa videl banderov̌̌činu v 1947-m. Komsomol'skaja pravda, № 22, 27. 2. 2014 (26200). <http://pressa.ru/en/ reader/\#/magazines/komsomolskaya-pravda-moskva/issues/22-ch/pages/4/>. [online]. [cit. 30. 3. 2016].

GRYTSENKO, O. (2013): Ukrainian Protesters Flood Kiev After President Pulls Out of the EU deal. The Guardian, 24. 11. 2013. <https://www.theguardian.com/world/2013/ nov/24/ukraine-protesters-yanukovych-aborts-eu-deal-russia>. [online]. [cit. 14. 5 . 2016].

JílEK, V. a kol. (2015): Jazykové prostředky s potenciálem porušit normu v oblasti mediálního zpravodajství. [CD-ROM]. Olomouc.

KŘÍŽ, Z., SHEVCHUK, Z., ŠTEVKOV,P. (2015): Hybridní válka jako nový fenomén $v$ bezpečnostním prostředí Evropy. Praha, Ostrava.

KUBEŠA, M., SPIŠÁK, J. (2011): Hybridní hrozby a vývoj nové operační koncepce NATO. Obrana a strategie 11, 2011, č. 2, s. 5-16. <http://www.obranaastrategie.cz/ cs/aktualni-cislo-2-2011/clanky/hybridni-hrozby-avyvoj-nove-operacni-koncepcenato.html>. [online]. [cit. 12.6. 2016].

LOKOT, T. (2013): As Ukraine's Protests Escalate, \#Euromaidan Hashtag Lost in a Sea of Information. Global Voices, 6. 12. 2013. <https://globalvoices.org/2013/12/o6/asukraines-protests-escalate-euromaidan-hashtag-lost-in-sea-of-information>. [online]. [cit. 19. 8. 2016].

LOZA, J. (2014): «Pust' idut na vse četyre storony». Komsomol'skaja pravda, № 7, 23.1. 2014 (26185). <http://pressa.ru/en/reader/\#/magazines/komsomolskaya-pravdamoskva/issues/7-ch/pages/3/>. [online]. [cit. 22. 3. 2016].

LUHN, A. (2014): Russia Tightens Limit on Foreign Ownership of Media. The Guardian, 26. 9. 2014. <https://www.theguardian.com/world/2014/sep/26/russia-limit-foreignownership-media>. [online]. [cit. 8. 4. 2017].

Maidan 2.o: A Protest With Reservations. (2013). The Interpreter, 25. 11. 2013. <http:// www.interpretermag.com/maidan-2-0-a-protest-with-reservations/>. [online]. [cit. 29. 5. 2016].

McCOMBS, M. (2009): Agenda setting: nastolování agendy - masová média a veřejné mínění. [Z anglického originálu přeložil Tomáš Kačer a Vlastimil Nečas]. Praha.

ONUCH, O. (2015): 'Facebook Helped Me Do It': Understanding the EuroMaidan Protester 'Tool-Kit'. Studies in Ethnicity and Nationalism, vol. 15, 2015, Issue 1, s. 170-184. 
OVČINNIKOV, A. (2014): «Ura! Èto naša «russkaja vesna». Komsomol'skaja pravda, № 23, 3. 3. 2014 (26201). <http://pressa.ru/en/reader/\#/magazines/komsomolskayapravda-moskva/issues/23-p-2014/pages/3/>. [online]. [cit. 2. 4. 2016].

POBRZGEN, G. (2016): Facing reality after the Euromaidan: The Situation of Journalists and Media in Ukraine. <https://rsf.org/sites/default/files/journalists_and_media_in_ ukraine_-_rsf_2016.pdf>. [online]. [cit. 14. 2. 2017].

RÁCZ, A. (2015): Russia's Hybrid War in Ukraine. Helsinki.

REIFOVÁ, I. a kol. (2004): Slovník mediální komunikace. Praha.

RJABCEV, A., ROGOZA, A. (2014): Za vossojedinenije s Rossijej-96,77\% krymčan. Komsomol'skaja pravda, № 29, 18. 3. 2014 (26207). <http://pressa.ru/ru/reader/\#/ magazines/komsomolskaya-pravda-moskva/issues/29-2014/pages/2/>. [online]. [cit. 10. 4. 2016].

RONZHYN, A. (2014): The Use of Facebook and Twitter During the 2013-2014 Protests in Ukraine. <https://www.researchgate.net/publication/268979057_The_Use_of_ Facebook_and_Twitter_During_the_2013-2014_Protests_in_Ukraine>. [online]. [cit. 2. 3. 2017].

Ruská média. (2017). Ministerstvo zahraničních věcí České republiky. <https:// www.mzv.cz/jnp/cz/udalosti_a_media/media_ve_svete/jihovychodni_a_vychodni_ evropa/ruska_media.html>. [online]. [cit. 2. 4. 2017].

SHVEDA, Y., HO PARK, J. (2015): Ukraine's Revolution of Dignity: The Dynamics of Euromaidan. Journal of Eurasian Studies, Vol. 7, 2015, Issue 1, s. 85-91. <https://www. sciencedirect.com/science/article/pii/S1879366515000305>. [online]. [cit. 19. 7. 2016].

SMI i socmedija: oktjabr' 2016. (2016). Medijalogija, 10. 11. 2016. <http://www.mlg.ru/ ratings/socmedia/media/4485/>. [online]. [cit. 29. 1. 2017].

The Press in Russia. (2008). BBC News, 16. 5. 2008. <http://news.bbc.co.uk/2/hi/europe/ 4315129.stm>. [online]. [cit. 17. 4. 2017].

TUCKER, J. A., METZGER, M., PENFOLD-BROWN, D., BONNEAU, R., JOST, J.T., NAGLER, J. (2014): Protest in the Age of Social Media: Technology and Ukraine's \#Euromaidan. Carnegie Reporter, Vol. 7, 2014, No. 4. <https://medium.com/carnegiecorporation-international-peace-and/protest-in-the-age-of-social-media-7aegfd 940 bo6>. [online]. [cit. 17. 2. 2016].

Ty naš, a my tvoi. (2014). Komsomol'skaja pravda, №29, 18. 3. 2014 (26207). $<$ http://pressa.ru/ru/reader/\#/magazines/komsomolskaya-pravda-moskva/issues/292014/pages/2/>. [online]. [cit. 10. 4. 2016].

VEEBEL, V. (2015): Russian Propaganda, Disinformation, and Estonia's Experience. <https://www.fpri.org/article/2015/10/russian-propaganda-disinformationand-estonias-experience/>. [online]. [cit. 25. 7. 2016].

WOOD, E. A., POMERANZ, W. E., MERRY, W. E., TRUDOLYUBOV, M. (2016): Roots of Russia's War in Ukraine. New York. 
ZELENKA, P. (2014): Je konflikt na Ukrajině „hybridní válkou“? Ústav mezinárodních vztahů. <http://www.iir.cz/en/article/je-konflikt-na-ukrajine-hybridni-valkou>. [online]. [cit. 10. 4. 2016].

Článek vznikl v rámci řěení grantu č. Do5-45 „Mediální konstrukce vlastenectví ve vybraných ruských médiích"Interního grantového systému Metropolitní univerzity Praha, o. p. s.

\section{O autorkách}

Eva Niklesová, Metropolitan University Prague, Department of Media Studies, Prague, Czech Republic,eva.niklesova@mup.cz

Ekaterina Shlygina, Metropolitan University Prague, Department of Media Studies, Prague, Czech Republic, e.shlygina@gmail.com 
